\title{
Dimensions, Issues, and Bills: Appropriations Voting on the House Floor
}

\author{
Michael H. Crespin The University of Georgia \\ David W. Rohde Duke University
}

One of the fundamental findings in the congressional literature is that one or sometimes two dimensions can successfully describe roll-call voting. In this paper we investigate if we can reach the same conclusions about low dimensionality when we divide the roll-call agenda into subsets of relatively homogeneous subject matter. We are primarily interested in the degree to which the same ordering of representatives is yielded across these different groups of votes. To conduct our analysis we focus on all roll calls on the 13 annual appropriations bills across eight congresses. When we concentrate on these smaller issue areas, we find that voting is multidimensional and members do not vote in a consistent ideological fashion across all issue areas.



ne of the most well-known theoretical models in political science is the spatial model of voting, first introduced by Duncan Black (1948) and Anthony Downs (1957). Although scholars across many of the political science subfields have applied the model in their areas of research, the model plays an especially prominent role in the foundational theories in the congressional literature (Cox and McCubbins 1993, 2005, 2007; Krehbiel 1991, 1998). ${ }^{1}$ Soon after the introduction of the model, scholars struggled to develop ways to measure the voting behavior of elected officials in order to place them on an ideological scale. For many, Keith Poole and Howard Rosenthal (1991, 1997, 2007) went a long way towards solving the problem with the introduction of NOMINATE.

Few developments in the last quarter century have had as much impact on congressional research, in particular, as the creation of the NOMINATE procedure for roll-call analysis. Poole and Rosenthal employed the technique, based on a simple spatial model with probabilistic voting, to recover legislators' positions and roll-call outcomes across the entire history of congressional voting. Based on this analysis, they conclude that " $[\mathrm{c}]$ ongressional roll-call voting, throughout most of American history, has had a simple structure. A two-dimensional spatial model that allows for a linear time trend accounts for most of roll-call voting" (Poole and Rosenthal 2007, 70). Moreover, results for congresses over the last few decades yield an even simpler picture of a Congress that reflects a "polarized, unidimensional world" (Poole and Rosenthal 2007, 318, emphasis ours) that divides the two major political parties on economic issues.

If these and the other results of Poole and Rosenthal's work based on the NOMINATE procedure-alone, jointly, and with coauthors-were the sum total of their impact, the consequences of their efforts would have been substantial. There was, however, much more. They made available to the research community their roll-call data, their NOMINATE results, and the software to permit other scholars to create their own roll-call analyses. Many researchers took advantage of this professional generosity and used the data and techniques to enrich substantially our knowledge of legislative politics in the United States and around the world, as well as to expand the applications to the study of courts and regulatory agencies.

In this paper we intend to follow in these footsteps by taking a finer-grained look at roll calls in the contemporary House of Representatives. Specifically, our interest is in whether the same conclusions about low dimensionality are reached when we divide the roll-call agenda into subsets of relatively

\footnotetext{
${ }^{1}$ Data and supporting materials will be made available upon publication at http://crespin.myweb.uga.edu. These models all build upon the work of Hotelling (1929).
}

The Journal of Politics, Vol. 72, No. 4, October 2010, Pp. 976-989

doi:10.1017/S0022381610000472

(C) Southern Political Science Association, 2010

ISSN 0022-3816 
homogeneous subject matter and compute NOMINATE scores separately within each group. While other scholars have questioned the two dimension results based on statistics such as the reported eigenvalues and proportional reduction in error (Roberts, Smith, and Haptonstahl 2009) or by using different scaling techniques (Heckman and Snyder 1997), we are primarily interested in the degree to which the same ordering of representatives is yielded by the NOMINATE procedure across different groups of votes. We feel that examining the ordering of members across issues is essential since a great deal of the theoretical and empirical research on American institutions is based on correctly identifying and measuring medians and pivots. Therefore, it is vital that our measures can accurately describe those positions. If medians and pivots change depending on the issue at hand, then it may be inappropriate to test hypotheses with NOMINATE scores based on all votes in a given time frame. ${ }^{2}$

If we find that voting is multidimensional and members do not vote in a similar fashion across issues, then there may be consequences for many areas of research across political science that rely on measuring preferences. For example, scholars have used a version of the NOMINATE procedure based on all roll-call votes in a congress to predict behavior or measure pivot points on specific issues such as the inclusion of treaty reservations (Auerswald and Maltzman 2003), tobacco and alcoholic beverages (Taylor 2003), women's and reproductive issues (Swers 1998), free trade (Crichlow 2002), confirming judicial nominees (Binder and Maltzman 2002; Shipan and Shannon 2003), and voting for presidential candidates (Jenkins and Sala 1998). The idea of issue-specific versus general voting scores is present in the committee preference outlier debates (Cox and McCubbins 1993; Gilligan and Krehbiel 1990; Groseclose 1994; Hall and Groffman 1990; Krehbiel 1991, 1994; Shepsle and Weingast 1995; Weingast and Marshall 1988). The divided government and gridlock literature relies on measures of distance between the President and key players in the House and Senate (Binder 1999; Brady and Volden 1998; Edwards, Barrett, and Peake 1997; Fiorina 1996; Kelly 1993; Krehbiel 1998; Mayhew 1991). Measuring the

\footnotetext{
${ }^{2}$ Since our focus is really on the set of votes used to estimate legislators' positions and not the statistical technique, our argument is very general and not exclusive to the NOMINATE procedure or just the House of Representatives. It is also applicable to other measures of legislative voting behavior such as those developed by Clinton, Jackman, and Rivers (2004). We concentrate on NOMINATE since it is the most widely used estimation technique.
}

correct pivot point is also an important variable in studies related to "killer amendments" since the killer amendments are often on an issue separate from the underlying bill. ${ }^{3}$ Finally, chamber and party medians (or filibuster and veto pivots) are vital to some of the foundational theoretical works in legislative politics (Cox and McCubbins 1993, 2005, 2007; Krehbiel 1991, 1998). ${ }^{4}$

Although these works do not exclusively rely on NOMINATE, each of them either implicitly or explicitly share the fundamental problems related to dimensionality and measuring the preferences of elected officials. As such, we do not cite these works to make the case that their conclusions no longer stand or that anyone should diminish their contributions. Instead we cite them to demonstrate that the points we discuss below echo throughout many of the seminal works on institutional politics. As we will make clear, our purpose here is not to contest or criticize the NOMINATE technique or the main substantive conclusions drawn from its use. ${ }^{5}$ Rather, we hope that by employing this additional perspective we will be able to enrich the knowledge gleaned from the technique and offer some caveats about some of the uses for the traditional NOMINATE scores.

\section{Voting Consistency and Dimensionality}

An important part of our argument about a multidimensional Congress is that members do not vote consistently across all issues. If members were identically ranked from left to right for every issue, then we could safely say that Congress is a one dimensional space. Alternatively, if this ranking changed depending on the issue, then it is likely that more than one dimension is necessary to accurately describe the U.S. Congress, at least for certain purposes or issues. In order to see a higher dimensional Congress, our measurements should yield significantly different positions for a substantial number of members across issues.

\footnotetext{
${ }^{3}$ A partial list of killer amendment research includes Riker (1982), Poole and Rosenthal (1997), Wilkerson (1999), Jenkins and Munger (2003), and Finocchiaro and Jenkins (2008).

${ }^{4}$ See Poole and Rosenthal (2007: chap. 11) for a more complete discussion of "The NOMINATE Literature."

${ }^{5}$ See Koford (1989), Poole, Rosenthal, and Koford (1991), and Rosenthal (1992) for a debate about the NOMINATE techniques and dimensionality.
} 
We offer a visual explanation of our theory in Figure 1 where we present a hypothetical legislature with five members. In each panel, we can align the members from the most liberal to the most conservative based on their voting behavior across two issues, $\mathrm{X}$ and $\mathrm{Y}$. In this example, we hold the ordering constant for issue $\mathrm{X}$ but allow it to vary for issue $\mathrm{Y}$. In the first panel (1A), members are ordered 1, 2, 3, 4, 5 from liberal to conservative on both issues. This allows us to classify member 3 as the median for issues $\mathrm{X}$ and $\mathrm{Y}$. In terms of dimensionality, we can accurately describe voting in this "legislature" as one dimensional. In the second panel, voting is not consistent at all as the ordering for issue $\mathrm{Y}$ is now $2,4,5,1,3$. So, while member one is the most liberal member on issue $\mathrm{X}$, she is now the second most conservative on issue $\mathrm{Y}$. Unlike the voting described in panel $1 \mathrm{~A}$, the median member is unique for both issues as member 3 is still the median for issue $\mathrm{X}$, but now member 5 is the median member for issue Y. Clearly, this "legislature" is not one dimensional. Finally, panel 1C depicts voting that is moderately consistent. Members 1, 4, and 5 vote in an identical fashion on both issues, but there is some movement between members 2 and 3 and now member 2 is the new median member on issue $\mathrm{Y}$. We argue here, and will present evidence below, that voting in the U.S. Congress looks more like panel C (and sometimes closer to panel B) compared to the voting depicted in panel A. Specifically, we will show that members do not always vote in a consistent fashion across all issues.

This variation in voting across issues can come from several different sources. Taking an example from Fenno (1977), a member might represent an ideologically heterogeneous district and have to vote one way (perhaps liberally) on issues important to urban constituents and another way (conservatively) on rural issue. It is also possible that a member will vote with her district on topics that are salient back home, but then vote with the party on other areas that are important to the leadership. Finally, there might be policy areas where a member votes her own personal policy preferences that are distinct from the district or the party. For our results to be valid, it is not necessary to take a strong stance on which factors influence a member's voting decision. We feel it is only necessary to demonstrate that it is plausible to imagine situations in which a member does not vote in an ideologically consistent fashion across all issues.

Before moving on to more systematic tests of our hypotheses, we provide an example of a current member of Congress, Dan Lipinski (IL-3), to illustrate our point. When it comes to one issue, abortion,

\section{Figure 1 Comparison of Voting Behavior Across Issues}

1A. Perfectly Consistent One Dimension Voting

\begin{tabular}{|c|c|c|c|c|c|c|}
\hline & & \multicolumn{5}{|c|}{ Issue $\mathbf{X}$} \\
\hline & & \multicolumn{2}{|c|}{ Liberal } & & \multicolumn{2}{|c|}{ Conservative } \\
\hline \multirow{5}{*}{ 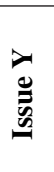 } & \multirow{5}{*}{$\begin{array}{l}\dot{\jmath} \\
\dot{0} \\
\dot{0}\end{array}$} & 1 & & & & \\
\hline & & & 2 & & & \\
\hline & & & & 3 & & \\
\hline & & & & & 4 & \\
\hline & & & & & & 5 \\
\hline
\end{tabular}

Issue X median - Member 3, Issue Y median - Member 3

1B. Inconsistent High Dimension Voting



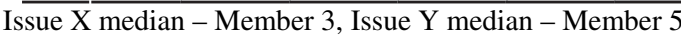

1C. Moderately Consistent Low Dimension Voting

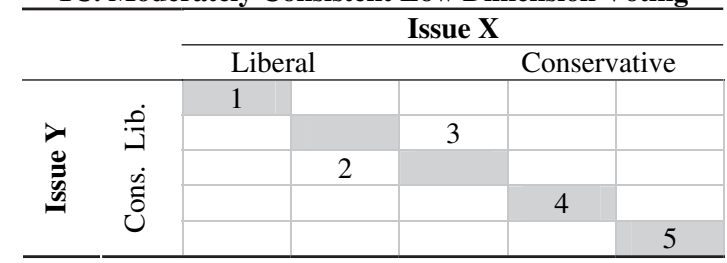

Issue X median - Member 3, Issue Y median - Member 2

Note: This figure provides a visual explanation of our expectations regarding the consistency of voting across multiple issues. As the number of members off the shaded diagonal increases, consistency decreases.

Lipinski is quite conservative. In fact, he received a perfect score of 100 from the National Right to Life Committee in 2006. Conversely, when voting on labor issues, Lipinski was liberal enough to earn a perfect voting score from the AFL-CIO. ${ }^{6}$ This means that on one issue, abortion, Lipinski lines up with the most conservative members in the chamber but on another issue, labor, he votes with the most liberal representatives. Lipinski's DW-NOMINATE score during this time-period was -.31 (on a scale from -1 to 1 with negative scores corresponding to liberal voting records) and his hometown Chicago Tribune editorial board describes Lipinski as a "moderate Democrat." 7 So, to call Lipinski a moderate is an accurate reflection of his overall voting record but the

\footnotetext{
${ }^{6}$ Interest group scores are available from Project Vote Smart (http://www.votesmart.org)

7"Choices for the House," Chicago Tribune, 1/15/2008. http:// archives.chicagotribune.com/2008/jan/15/opinion/chi-0115edit2jan15 [accessed 4/08/2009]
} 
label is wrong, in opposite directions, on both abortion and labor issues.

The reason this point is important lies in the use of NOMINATE scores. When scholars use a these scores to explain voting behavior, or measure a median or pivot for an individual bill, they are making the assumption that the score is an accurate description of a member's voting behavior on that topic. In reality, NOMINATE is an average of their voting behavior across an entire congress (or career depending on the type of NOMINATE). This means that the NOMINATE score may not reflect very well how a member might vote on some issues.

This problem is applicable to other areas of research as well. For example, when scholars try to predict if a judicial nominee will be confirmed, they frequently control for the distance between the president and important members of the judiciary committee. The concept of interest is really how far apart the president and the member are on the judicial nominee. However, it is usually measured with a NOMINATE score that may or may not accurately represent the member's position on that particular nominee. If the score does not reflect the correct position, then researchers are introducing measurement error into their statistical models.

\section{Explanations for a Low vs. Multidimensional Congress}

As we noted above, Poole and Rosenthal's long-term analysis of congressional voting concluded that at most times, and especially recently, low dimensionality accurately describes the voting patterns. Yet even within this broad and convincing generalization there are nuances. The authors make clear that at certain times the explanatory power of the first dimension declined and the impact of the second dimension became more substantial (Poole and Rosenthal 2007, 65). This was especially true during the breakup of the party systems around 1820 and 1860, but it was also somewhat characteristic of longer periods like the years after World War II (which Poole and Rosenthal (2007, 54-55) characterize as the "threeparty system"). Other researchers, (Potoski and Talbert 2000; Roberts, Smith, and Haptonstahl 2009; Talbert and Potoski 2002) also uncovered evidence that indicates the picture of the unidimensional Congress may need at least some qualification.

In a paper examining distributive versus partisan voting, Hurwitz, Moiles, and Rohde (2001) analyzed voting on agriculture issues in the $104^{\text {th }}$ House on the heels of the Republican takeover of Congress after the
1994 elections. They found that some of the roll calls involving policy change produced divisions that fell almost perfectly along party lines, and thus were prototypical first-dimension votes. On the other hand, the votes dealing with particular support programs generally yielded voting patterns that completely cut across party lines. Obviously the same first dimension could not account for these other patterns. One point that Hurwitz, Moiles, and Rohde focused on was that it was unusual for the House to vote on the individual distributive issues that produced the cross-cutting patterns. But this is not the same thing as saying that the interests and cleavages that produced the cross-cutting divisions were not present in other congresses. In essence, it is possible for preferences to be multidimensional, but these preferences do not reveal themselves because the issues do not receive enough roll calls to show up during normal analyses. Although the roll-call votes may lead us to believe that voting is unidimensional, we should not necessarily conclude that preferences are unidimensional as well. To explore this possibility and to examine its effects on conclusions about the dimensionality of voting, one would have to find a way to isolate sets of roll calls that would exhibit sufficient variation in subject matter. The annually repeated appropriations process appeared to offer the opportunity to do just that, by pooling votes from consecutive congresses.

The key to our effort is assuring sufficient comparability across years. Each year the House Appropriations Committee reports one bill from each of its 13 subcommittees, dealing with appropriations for the programs within that subcommittee's jurisdiction. ${ }^{8}$ Moreover, during the period on which we focus (the $100^{\text {th }}$ through the $107^{\text {th }}$ Congresses, 1987-2003), the jurisdictions of the subcommittees stayed the same. Thus, we could be sure that the subject matter of the votes within each jurisdiction would be more similar to each other than to the roll calls from another subcommittee. By this device we hoped to get a larger number of roll calls linked to crosscutting issues than would be the case by analyzing a single congress. From such data we could discover how much variation in positions members exhibited from one issue to another and the degrees to which we can characterize these separate issues by low dimensionality.

\footnotetext{
${ }^{8}$ In addition the Committee also reports supplemental, special, and omnibus bills that involve multiple subcommittee jurisdictions. Because of the diversity of the subject matters involved in these bills, we do not include them in our analysis.
} 


\section{Data and Methods}

In order to test our expectations regarding variations in member voting behavior across different issue areas, we analyze all floor roll-call votes on the bills stemming from each of the subcommittees of the House Committee on Appropriations for the $100^{\text {th }}-107^{\text {th }}$ Congress. Traditionally, Congress annually considers a separate bill for all of these subcommittees each with a defined jurisdiction. Table 1 gives the names of each of the subcommittees which are descriptive enough so that we can get a good sense of their jurisdictions.

We feel appropriations roll calls are particularly suitable for this analysis because Poole and Rosenthal find that the "first dimension almost always picks up the fundamental economic issues that separate the two major political parties" $(2007,32)$. This means that searching for multidimensionality within a set of votes that primarily deals with economic matters (i.e., government spending) is a hard test. An easy test would be to compare votes on issues that we already know split members on something other than party lines, such as race. Further, using votes on appropriations should not be viewed as only looking at a few bills over time. First and foremost, the thirteen bills collectively cover the whole policy spectrum of congressional policy making, but each subcommit-

\section{Table 1 Appropriations Subcommittees and Total Number of Roll Calls}

\begin{tabular}{lc}
\hline Subcommittee & $\begin{array}{c}\text { Number } \\
\text { of Votes }\end{array}$ \\
\hline $\begin{array}{l}\text { Agriculture, Rural Development, FDA } \\
\quad \text { and Related Agencies }\end{array}$ & 142 \\
Commerce, Justice, State and Judiciary & 184 \\
District of Columbia & 100 \\
Energy and Water Development & 116 \\
Foreign Operations, Export Financing & 139 \\
$\quad$ and Related Programs & \\
Interior & 236 \\
Labor, Health and Human Services, & 151 \\
$\quad$ and Education & 118 \\
Legislative & 53 \\
Military Construction & 93 \\
National Security (Defense) & 93 \\
Transportation & 145 \\
Treasury, Postal Service and General & \\
$\quad$ Government & 191 \\
Veterans Affairs, Housing and Urban & \\
$\quad$ Development and Independent Agencies & \\
All Appropriations Votes &
\end{tabular}

tee's individual jurisdiction is comparatively homogeneous. Second, when we divide the number of roll calls into the nine issues areas from the Rohde (2010) dataset, appropriations votes make up the plurality of votes each year. ${ }^{9}$ Third, by using this subset of votes we have enough roll calls for each subcommittee to have confidence in the NOMINATE scores. Finally, within the appropriations category, there is a good mix of vote types (i.e., amendment, procedural, and final passage). Based on these reasons, we think that using appropriation voting to test for multidimensionality is appropriate. ${ }^{10}$

Since we will use the W-NOMINATE procedure developed by Poole and Rosenthal (1997) to scale the roll-call votes, we need enough votes for each of the 13 jurisdictions. To get a sufficient number of rollcall votes, we collected data from the $100^{\text {th }}$ through the $107^{\text {th }}$ Congress and formed 14 roll-call matrices, one for each of the subcommittees and an additional one that includes all appropriations votes. If a member served in all of the eight congresses, we concatenated the votes from those congresses. If a member did not serve across our entire dataset, they received a code of 0 "Not in Congress at the time of the Roll Call" for all of those votes. We then estimate the NOMINATE scores separately for each of the 14 matrices. Because we do not estimate the scores within the same matrix and anchor using similar members, individual scores are not directly comparable across the subcommittees. However, we feel that comparing a member's rank in terms of overall liberal or conservativeness is appropriate. Although combining votes across Congresses can be problematic, because we are including a specific set of votes dealing with similar issue areas and those areas are constant over time, we feel the gains from our technique outweigh any shortfalls. ${ }^{11}$

\footnotetext{
${ }^{9}$ The categories are (1) Symbolic, Internal and Procedural, (2) Appropriations, (3) Defense, (4) Foreign Policy, (5) Taxes and Budget Issues, (6) Energy and Environment, (7) Government Operations, (8) Welfare and Human Services, and (9) Miscellaneous Domestic.

${ }^{10}$ To isolate the appropriate votes, we employed the Roll-Call Voting dataset originally created by Rohde (2010). Within the issue type coding, it separates out legislative issues from appropriations issues. For example, the dataset codes a vote dealing with the Department of Defense building the MX missile differently from a vote on an amendment to the National Security appropriations bill to fund (or not fund) the missile. This way, we can be sure we only include appropriations matters in this particular dataset.

${ }^{11}$ We are indebted to Keith Poole for suggesting this technique and for offering advice on the number of roll calls required for a dependable scale.
} 
Table 1 also lists the number of votes we scale for each of the subcommittees. For all but one area, military construction, we were able to code a sufficient number of votes. Since there were only 53 votes on bills from this subcommittee, we will exercise caution in drawing any inferences for this area of appropriations. However, as we will show below, the results are not specific to any one particular subcommittee. Further, to minimize problems related to directly comparing individual NOMINATE score across the different areas, most of our results either rely on comparing sets of members where members are coded into equally sized groups based on their relative ideology or on a system of rank ordering.

\section{Analysis}

Arguably, there is no one piece of evidence or "smoking gun" that will prove that voting patterns vary significantly depending on the issue at hand. So, in order to demonstrate that voting is not always consistent, we have devised tables and figures that present the data in various ways. Some of our analysis will focus on members around the median of the scale, while others will look at the full set of members. Although no one aspect of the presentation is likely to make our case conclusively, and while each may have some weakness, we believe that the cumulative effect of the evidence makes a convincing case in support of our argument.

\section{Preliminary Evidence of Dimensionality}

Our theoretical argument suggests that when we compare more narrowly defined issue areas, it might no longer be plausible to explain voting with only one or two dimensions. This hypothesis runs contrary to what Poole and Rosenthal found in the larger aggregates. To begin our examination of this question, we present two Skree plots of the eigenvalues of the double-centered agreement score matrix (Figure 2). The "elbow" in the Skree plots gives an indication of the number of dimensions needed to explain the data. The left portion of Figure 2 provides an example of one dimensional voting, constructed from all of the roll-call votes from the $104^{\text {th }}$ Congress. Here, the sharp "elbow" at the second dimension gives a good indication that the data are one-dimensional. This is not the case for the Skree plot for the all appropriations votes category in our dataset. Here, there is evidence of at least three and maybe more dimensions. This gives us an early indication that voting is not always unidimensional.

\section{Comparing Medians}

In order to show that voting is not always consistent, we now turn to a comparison of medians across each of the 13 subcommittees as well as the "all appropriations" category. The median of the chamber, or party, has become a critical variable in much of the congressional literature associated with partisan politics (See, e.g., Cox and McCubbins 1993, 2005, 2007 or Krehbiel 1998). If the median is not consistent

Figure 2 Skree Plots of the Eigenvalues of the Double Centered Squared Distance Matrix
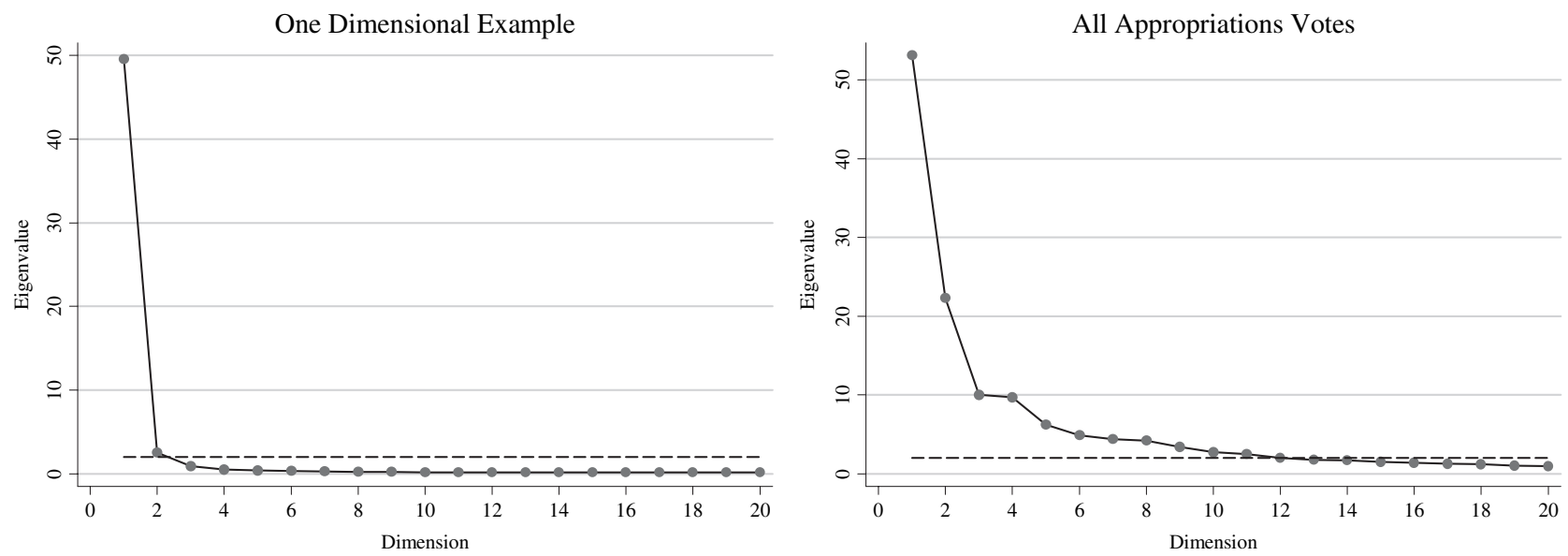

Note: These figures represent Skree plots of the eigenvalues of the double centered squared distance matrix. The position of the "elbow" is an indication of the number of dimensions. 
across issue areas then future researchers should think carefully about how they measure this cutpoint, especially if the research is issue specific.

One way to compare medians would be to determine the median member for each set of votes and compare her placement across all the issue areas. However, since NOMINATE scores are estimates and there is a degree of uncertainty associated with each score (see Lewis and Poole 2004), declaring one member the median of the chamber or party and testing if she is unique across issues would not be a reliable approach. Instead of picking one median, we divide a subset of members into an odd number of equally sized groups and then compare the placement of the members in the median group for one issue area to their relative placement in all the other sets of votes. This approach has the advantage of placing the least demands on the data, relying only on ordinality. Since the median can be a relative position depending on the set of members at hand, we only work with the subset of members who have NOMINATE scores on each of the subcommittee measures as well as a score for all appropriations votes. If a member did not have a score for any of the 14 measures, we dropped them from this portion of the analysis. Once we obtained the initial subset, we then ordered the remaining members from the most liberal to the most conservative on each of the sets of votes and then sorted them into 11 equally sized groups. We placed the most liberal members in the first group and the most conservative in the last. Based on the sample size
(437) and number of groups (11), we then label the $6^{\text {th }}$ group the median group of the "chamber," the $3^{\text {rd }}$ the Democratic median group and the $9^{\text {th }}$ the Republican median group. Once we know who is in the median group for any set of votes, we can then determine if the same members are in the median group for other sets of votes. If voting is perfectly consistent across issues, then we would expect the members in the median group for one set of votes to be the same for the others. If voting is not consistent, then members who fall into the median group for one set of votes may "move" to different groups for other types of votes.

We begin our analysis of median comparisons with Table 2. Here we determined the set of 40 members who were in the median or sixth group for the "all appropriations" category and report a set of summary statistics for their placement across each of the 13 subcommittee sets of votes. If voting is perfectly consistent then the mean group statistic, minimum, and maximum should all be 6 and the standard deviation would then be zero. According to the results in Table 2, this is not the case. For example, the members who were in the median group for the all appropriations votes category had a mean group score of 6.5 on agriculture votes. This suggests that, on average, members who were in the median for all appropriations voted in a more conservative fashion on agriculture votes. For each of the subcommittee measures, the mean group score is close to 6 , as we would expect since most members

TAble 2 All Appropriation Median Members Compared to Subcommittee Voting

\begin{tabular}{|c|c|c|c|c|c|c|c|c|c|c|c|c|}
\hline \multirow[b]{2}{*}{ Committee } & \multicolumn{4}{|c|}{$\begin{array}{l}\text { Chamber } \\
\text { Median }\end{array}$} & \multicolumn{4}{|c|}{$\begin{array}{c}\text { Democratic } \\
\text { Median }\end{array}$} & \multicolumn{4}{|c|}{$\begin{array}{c}\text { Republican } \\
\text { Median }\end{array}$} \\
\hline & Mean Group & S.D. & Min & $\operatorname{Max}$ & Mean Group & S.D. & Min & $\operatorname{Max}$ & Mean Group & S.D. & Min & $\operatorname{Max}$ \\
\hline Ag. & 6.5 & 1.3 & 3 & 10 & 3.0 & 1.1 & 1 & 6 & 8.9 & 1.2 & 6 & 11 \\
\hline Comm. & 6.1 & 0.6 & 5 & 7 & 2.8 & 0.9 & 1 & 4 & 9.0 & 0.8 & 8 & 10 \\
\hline D.C. & 6.0 & 1.0 & 4 & 8 & 2.7 & 1.1 & 1 & 4 & 9.3 & 1.1 & 7 & 11 \\
\hline Defense & 6.2 & 1.9 & 2 & 9 & 3.4 & 1.7 & 1 & 7 & 9.0 & 1.8 & 4 & 11 \\
\hline Energy & 6.6 & 1.6 & 4 & 11 & 2.9 & 1.4 & 1 & 6 & 8.9 & 1.3 & 7 & 11 \\
\hline Foreign Affairs & 6.1 & 1.0 & 4 & 9 & 2.9 & 1.0 & 1 & 5 & 9.3 & 1.1 & 7 & 11 \\
\hline HUD & 6.0 & 0.7 & 4 & 8 & 3.0 & 0.7 & 1 & 4 & 9.2 & 0.8 & 8 & 11 \\
\hline Interior & 6.1 & 0.7 & 5 & 8 & 3.0 & 0.7 & 2 & 5 & 9.0 & 0.8 & 7 & 10 \\
\hline Labor & 6.1 & 0.6 & 5 & 8 & 2.7 & 1.0 & 1 & 5 & 9.0 & 0.7 & 7 & 10 \\
\hline Leg. Branch & 6.3 & 1.1 & 5 & 10 & 3.0 & 1.3 & 1 & 5 & 9.2 & 1.2 & 7 & 11 \\
\hline Military Const. & 6.5 & 1.7 & 3 & 11 & 3.0 & 1.4 & 1 & 5 & 9.1 & 1.4 & 6 & 11 \\
\hline Transportation & 6.4 & 1.1 & 4 & 9 & 2.9 & 1.2 & 1 & 5 & 9.0 & 1.1 & 7 & 11 \\
\hline Treasury & 6.0 & 0.8 & 4 & 8 & 2.8 & 1.0 & 1 & 4 & 9.3 & 0.9 & 7 & 11 \\
\hline Average: & 6.2 & 1.1 & 4.0 & 8.9 & 2.9 & 1.1 & 1.1 & 5.0 & 9.1 & 1.1 & 6.8 & 10.8 \\
\hline
\end{tabular}

Note: This table reports summary statistics on subcommittee voting for the set of members who scored in the median group of 11 groupings on all appropriations votes. The respective median groups were six, three, and nine on all appropriations votes. 
should vote in a similar fashion across issues. However, this does not mean all members vote in a consistent fashion. The standard deviation statistic gives us a measure of spread around the mean and since we are working with a uniform distribution, one standard deviation corresponds to one group or 40 members. In eight of the 13 cases, the standard deviation is at or above 1 demonstrating that there is considerable degree of movement around the mean. Finally, the minimum and maximum statistics illustrate that median members from one category can vote in either a liberal or conservative fashion on another set of votes. Some members who were in group 6 on the "all appropriations" scale ranged from a low of group 2 on Defense appropriations to a high of group 11 for Energy and Military Construction. The final row in the table displays the mean of the measures for each of the subcommittees.

To put these measures in perspective, we can follow a member who falls into the median for all votes and see where they score on the different subsets. Chris Shays $(\mathrm{R}-\mathrm{CT})$ was in the median grouping for all appropriations votes as well as for Foreign, HUD, Interior, Labor, and Military Construction. In contrast, when it comes to voting on Agriculture appropriations, Shays falls into the $10^{\text {th }}$ grouping. Since there are 40 members in each group, this is a difference of at least 120 members to the right for Shays. For Defense appropriations, Shays falls into the second grouping. If we were to compare his voting on Agriculture to Defense, he moved at least 280 members from the right to the left! ${ }^{12}$ Clearly, all members do not vote the same across all issues.

Table 2 also displays similar statistics for the Democratic and Republican Party medians. Again we see similar patterns with means near the party median but standard deviations near 1 and ranges of minimums and maximums averaging about 4 . In a few cases, especially for the Democrats, the ranges are quite large. For example, Patricia Schroeder (D-CO) was among the median members of her party for all appropriations votes but was near the median of the chamber for Agriculture appropriations voting. Three Democrats, Ron Coleman (D-TX), Steny Hoyer (D-MD) and Eddie Bernice Johnson (D-TX) were at their party median for all appropriations votes but one group to the right of the chamber median for

\footnotetext{
${ }^{12}$ These are conservative estimates because we assume, for instance, that Shays is the most conservative member in group 6 and the least conservative in group 10. Even though there is some uncertainty associated with each score, this movement of at least 280 members is telling.
}

Defense appropriations. Some Republicans exhibited similar voting patterns.

In Table 3, we present the average of the means, standard deviations, minimums, and maximums for the median groups for each of the appropriation categories on all of the other subcommittee votes. This allows us to compare how the members from the median groups in one subcommittee area voted across each of the other issue areas. For example, the median group on Agriculture appropriations voting had a mean group score of 6.5 on each of the other issues with a standard deviation of 1.4. The average minimum and maximum was 3.3 and 9.6 across the other 12 subcommittees. For each of the 13 subcommittees, the average standard deviation was above 1 and there was clear movement into different groups by individual members. Again, it seems reasonable to conclude that the medians can change depending on the particular issue area. Although we do not go into detail for each individual member on these tables, based on this evidence we can begin to make the claim that some, but not all, members may have different types of voting behavior depending on the issue at hand. That is, not all members are conservative, or liberal, across all issues.

\section{Comparisons of Ordinal Rankings by Subcommittee Bill}

Turning to the subcommittee-specific rankings of members, an appropriate initial comparison is to

\section{Table 3 Descriptive Statistics for Subcommittee Median Group on all other Subcommittees}

\begin{tabular}{lcccr}
\hline & \multicolumn{4}{c}{ Chamber Descriptive Statistics } \\
\cline { 2 - 5 } Committee & Mean & S.D. & Min & Max \\
\hline Ag. & 6.5 & 1.4 & 3.3 & 9.6 \\
Comm. & 6.4 & 1.2 & 3.9 & 9.3 \\
D.C. & 6.2 & 1.5 & 3.4 & 9.6 \\
Defense & 6.8 & 2.2 & 2.1 & 11.0 \\
Energy & 6.2 & 1.6 & 2.2 & 9.3 \\
Foreign Affairs & 6.2 & 1.4 & 3.3 & 9.3 \\
HUD & 6.3 & 1.3 & 3.8 & 9.7 \\
Interior & 6.4 & 1.3 & 3.7 & 9.3 \\
Labor & 6.3 & 1.3 & 3.7 & 9.3 \\
Leg. Branch & 6.3 & 1.4 & 3.1 & 10.3 \\
Military Const. & 6.8 & 2.1 & 3.5 & 10.9 \\
Transportation & 6.6 & 1.3 & 4.2 & 9.6 \\
Treasury & 6.2 & 1.4 & 3.7 & 9.6 \\
\hline
\end{tabular}

Note: In each case, the median group is group 6. We compare the members in the median group on each subcommittee with their average group placement on each of the other issue areas. 
Table 4 Subcommittee Decile Comparison

\begin{tabular}{|c|c|c|c|c|c|c|c|c|c|c|c|}
\hline \multicolumn{12}{|c|}{ 4A. Energy and Defense } \\
\hline & & 1 & 2 & 3 & 4 & 5 & 6 & 7 & 8 & 9 & 10 \\
\hline \multirow{10}{*}{ Energy } & 1 & 5.8 & 2.6 & 1.3 & 0.5 & & & & & 0.2 & \\
\hline & 2 & 2.1 & 3.1 & 2.3 & 0.7 & 1.0 & & 0.2 & & & \\
\hline & 3 & 0.7 & 2.6 & 2.3 & 1.5 & 0.8 & 0.7 & 0.3 & & & \\
\hline & 4 & 0.8 & 0.3 & 1.2 & 2.3 & 2.8 & 1.2 & 1.5 & 0.2 & & \\
\hline & 5 & 0.2 & 0.7 & 0.7 & 2.8 & 0.8 & 1.5 & 1.2 & 0.7 & 0.2 & \\
\hline & 6 & 0.2 & 0.3 & 0.8 & 1.0 & 1.3 & 1.5 & 1.3 & 2.0 & 1.0 & 0.3 \\
\hline & 7 & & 0.2 & 0.5 & 0.3 & 1.2 & 1.5 & 1.7 & 1.7 & 2.0 & 0.8 \\
\hline & 8 & & 0.2 & 0.2 & 0.2 & 1.5 & 1.0 & 1.8 & 1.8 & 2.0 & 2.6 \\
\hline & 9 & & & 0.5 & 0.3 & 0.5 & 1.0 & 0.8 & 1.7 & 3.1 & 3.1 \\
\hline & 10 & 0.2 & & 0.3 & 0.3 & 0.2 & 1.7 & 1.2 & 2.1 & 1.5 & 3.1 \\
\hline \multicolumn{12}{|c|}{ 4B. D.C. and Labor } \\
\hline \multicolumn{12}{|c|}{ Labor } \\
\hline & & 1 & 2 & 3 & 4 & 5 & 6 & 7 & 8 & 9 & 10 \\
\hline \multirow[t]{10}{*}{ D.C. } & 1 & 5.3 & 3.3 & 1.0 & 0.1 & 0.3 & & & & & \\
\hline & 2 & 3.8 & 3.2 & 2.8 & 0.1 & 0.1 & & & & & \\
\hline & 3 & 0.7 & 1.8 & 4.5 & 2.5 & 0.6 & & & & & \\
\hline & 4 & 0.3 & 0.8 & 1.8 & 4.2 & 2.4 & 0.4 & 0.1 & & & \\
\hline & 5 & & & 0.6 & 2.9 & 4.6 & 1.7 & 0.1 & 0.1 & & \\
\hline & 6 & & & & 0.3 & 2.6 & 4.6 & 1.9 & 0.4 & & 0.1 \\
\hline & 7 & & & & & 0.1 & 3.1 & 3.5 & 2.6 & 0.4 & 0.3 \\
\hline & 8 & & & & & & 0.8 & 2.8 & 3.5 & 2.4 & 0.4 \\
\hline & 9 & & & & & & & 0.7 & 3.1 & 3.6 & 2.6 \\
\hline & 10 & & & & & & & 0.4 & 0.6 & 3.3 & 5.7 \\
\hline
\end{tabular}

Note: Cell entries represent the percent of members in each of the decile pairs. A higher percentage of members off the diagonal indicate members do not vote in a similar fashion across the two issues. Lower deciles represent more liberal scores

assess the degree to which the rankings are similar from one subcommittee to another. One way to do this is to again place members into groups, and then compare the groupings pair-wise across subcommittees. ${ }^{13}$ Unlike the median comparison where an odd number of groups are necessary we place members here into 10 equal groups (or deciles) for each subcommittee. Tables $4 \mathrm{~A}$ and $\mathrm{B}$, which are analogous to Figure 1, present two comparisons, one for the Energy and Defense subcommittees (4A) and one for D.C. and Labor (4B). If there were absolutely no relationship between the two rankings, we would expect one percent of the members to appear in each cell. It is readily apparent that the rankings are more related than that. Looking down the main diagonal of the table, one can see that most cells contain considerably more than one percent of the members,

\footnotetext{
${ }^{13}$ If a member did not have a score on either of the two categories we deleted them from the analysis.
}

especially near the endpoints. With no relationship the 10 cells on the diagonal should contain $10 \%$ of the members. In actuality they contain $25.6 \%$. Moreover, if we broaden our expectations to include the additional 18 cells that are within one rank either way of the diagonal, $60.8 \%$ of the members appear in those 28 cells. Thus there is clearly an underlying structure that ties the two scales together. On the other hand, the comparison of the two scales clearly does not reveal that they are identical or even nearly so. The "within one rank" standard of similarity is a fairly generous one, and yet fully $39.2 \%$ of the members' scores differ by more than that.

We selected the Energy-Defense pairing in Table $4 \mathrm{~A}$ precisely because it exhibits considerable divergence, but even the most similar pairs of rankings reveal enough differentiation to be analytically interesting. Table 4B shows the paired ranks for the D.C. and Labor subcommittees. Here fully $42.7 \%$ of the members fall on the diagonal, and $90 \%$ lie within one 
Table 5 Percent of Members More Than One Group Off Center

\begin{tabular}{|c|c|c|c|c|c|c|c|c|c|c|c|c|}
\hline & Ag. & Comm. & D.C. & Defense & Energy & $\begin{array}{c}\text { Foreign } \\
\text { Affairs }\end{array}$ & HUD & Interior & Labor & $\begin{array}{l}\text { Leg. } \\
\text { Branch }\end{array}$ & $\begin{array}{l}\text { Military } \\
\text { Const. }\end{array}$ & Trans. Treasury \\
\hline \multicolumn{13}{|l|}{ Ag. } \\
\hline Comm. & 17.0 & & & & & & & & & & & \\
\hline D.C. & 24.2 & 16.4 & & & & & & & & & & \\
\hline Defense & 42.0 & 36.3 & 32.8 & & & & & & & & & \\
\hline Energy & 26.0 & 25.2 & 35.0 & 39.0 & & & & & & & & \\
\hline Foreign & 26.0 & 19.6 & 14.3 & 36.6 & 33.0 & & & & & & & \\
\hline \multicolumn{13}{|l|}{ Affairs } \\
\hline HUD & 17.7 & 15.7 & 21.8 & 34.6 & 22.5 & 21.1 & & & & & & \\
\hline Interior & 23.9 & 13.5 & 15.0 & 34.3 & 26.2 & 16.4 & 11.3 & & & & & \\
\hline Labor & 19.3 & 11.8 & 10.0 & 34.1 & 28.9 & 13.9 & 15.6 & 10.8 & & & & \\
\hline $\begin{array}{l}\text { Leg. } \\
\text { Branch }\end{array}$ & 23.4 & 18.7 & 25.5 & 45.5 & 28.9 & 30.0 & 25.6 & 23.6 & 23.1 & & & \\
\hline $\begin{array}{l}\text { Military } \\
\text { Const. }\end{array}$ & 30.2 & 27.0 & 32.3 & 31.6 & 31.8 & 33.0 & 27.7 & 26.8 & 30.4 & 34.1 & & \\
\hline Transportation & 23.1 & 18.1 & 28.8 & 40.7 & 27.2 & 29.0 & 21.5 & 21.4 & 20.6 & 21.4 & 31.4 & \\
\hline Treasury & 21.3 & 12.7 & 19.2 & 37.7 & 28.0 & 18.9 & 17.5 & 14.9 & 15.5 & 20.1 & 29.1 & 21.0 \\
\hline
\end{tabular}

Note: This table lists all the possible pairings of subcommittees. The numbers in each cell show the proportion of the members whose scores are more than one decile different. A larger percentage indicates members do not vote in a similar fashion across the two issues

rank of the diagonal. That is a considerably stronger relationship than the previous comparison, but still $10 \%$ of the members differ by more than the generous one-rank standard.

Table 5 lists all the pairings of subcommittees, showing for each pair the percent of the members whose scores are outside the within one rank standard. Of the 78 comparisons, 38 (or 49\%) have onefourth or more of the members differing by more than one rank, and another 16 of the pairs $(20 \%)$ have 20 to $24.9 \%$ of the members meeting that standard. In our view, these comparisons demonstrate the accuracy of our expectations that a focus on a more fine-grained comparison of scales of members' positions would reveal that at this level there is considerable differentiation. The common underlying structure that dominates the results from the congress-by-congress NOMINATE scales constructed by Poole and Rosenthal is still visible in these comparisons. Also visible, however is substantial differentiation between the rankings based on jurisdiction-specific groups of roll calls. At this level of specificity, the "one-dimensional" characterization cannot be sustained.

\section{Correlation of Ranks}

As an additional example of members voting differently across the subcommittees, we present a matrix of Spearman correlations based on a ranking of members from the most liberal to the most conservative in Table $6 .{ }^{14}$ If members voted the same across each of the subcommittees, then correlations would all be 1 . In this case, 47 of the 78 correlations are between 90 and 100\%, 25 are between 80 and 89.9 and six are between 70 and 79.9. The large number of correlations over 90 suggests that members do vote in a similar fashion, but the correlation is not perfect. In order to present a better visualization of the correlation results, we performed an eigenvalue-eigenvector decomposition of the Spearman correlation matrix presented in Table 6 and then created a scatter plot of the first two eigenvectors shown in Figure 3. As we expected based on the relatively low correlations from Table 6, voting on Defense is a clear outlier.

In a final demonstration of subcommittee variation, Table 7 displays a comparison between the percent correctly predicted from our W-NOMINATE scaling and the equivalent measure for the same votes from the standard DW-NOMINATE scaling. As indicated by Table 7 , our separate scalings outperform the DW-NOMINATE scaling and once again, Defense and Military Construction are outliers. In fact, if we go back and examine the Defense category from

\footnotetext{
${ }^{14}$ An analogous figure using Kendal's Tau reveals similar patterns but with lower levels.
} 
Figure 3 Plot of First Two Eigenvectors of the Spearman Correlation Matrix

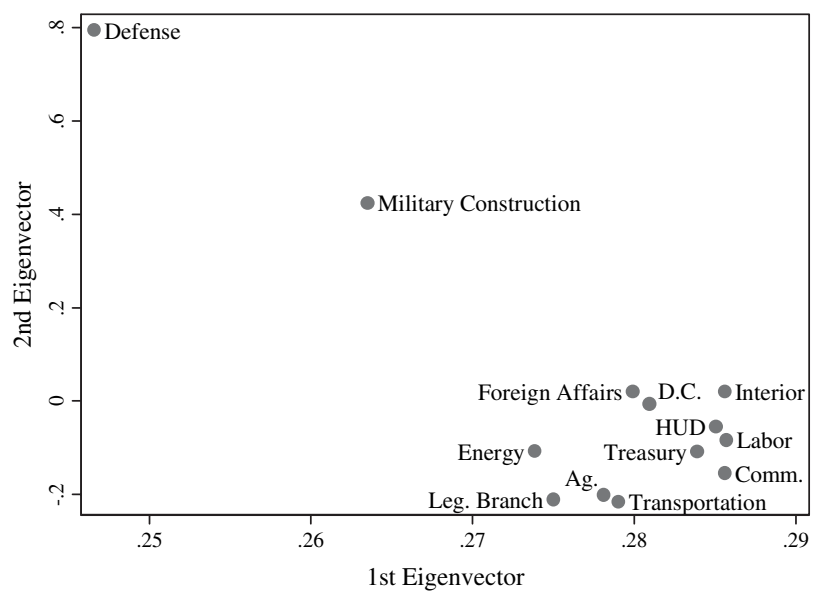

Note: This figure presents a plot of the first two eigenvectors of the spearman correlation matrix. The large distance between the Defense category and the others indicates the greatest variation in voting.

our other analyses it presents a higher degree of variability compared to the other subcommittees. When we compared members in the median group from the all appropriations votes category with how they ranked in the other categories in Table 2, the standard deviation on Defense votes was the highest at 1.9. Referring back to Table 3, the members who are in the median grouping for Defense have an average minimum ranking of 2.1 and maximum ranking of 11.0. This means that members who are at the median for Defense appropriations votes are some of the most liberal and conservative members for votes on many of the other categories. This result is also indicated by the high percentages from Table 5. When we compare Defense voting with Agriculture voting, a full $42 \%$ of members are more than one off the diagonal of the cross-tab. At the very least, there is strong evidence that defense appropriations voting is different when compared to voting on the other appropriation issues.

\section{Conclusion}

At the onset of this paper, we argued that while Congress as a whole can largely be described with one or maybe two dimensions, this does not necessarily mean that every issue can be neatly placed on a single dimension. By combining enough votes on a series of issue areas, we were able to demonstrate that some issues are multidimensional and members do not always vote in a consistent fashion on all issues. Through the lens of appropriations voting, we provided evidence that members can be close to the chamber or party median on one type of bill, but

TABLE 6 Spearman Correlation of Ranks

Foreign Leg. Military

Ag. Comm. D.C. Defense Energy Affairs HUD Interior Labor Branch Const. Trans. Treasury

\begin{tabular}{|c|c|c|c|c|c|c|c|c|c|c|c|c|}
\hline Ag. & & & & & & & & & & & & \\
\hline Comm. & 0.94 & & & & & & & & & & & \\
\hline D.C. & 0.89 & 0.94 & & & & & & & & & & \\
\hline Defense & 0.74 & 0.78 & 0.81 & & & & & & & & & \\
\hline Energy & 0.91 & 0.91 & 0.87 & 0.76 & & & & & & & & \\
\hline Foreign & 0.89 & 0.94 & 0.94 & 0.81 & 0.87 & & & & & & & \\
\hline Affairs & & & & & & & & & & & & \\
\hline HUD & 0.93 & 0.95 & 0.93 & 0.81 & 0.92 & 0.93 & & & & & & \\
\hline Interior & 0.92 & 0.96 & 0.94 & 0.83 & 0.90 & 0.95 & 0.96 & & & & & \\
\hline Labor & 0.93 & 0.97 & 0.96 & 0.80 & 0.90 & 0.95 & 0.95 & 0.96 & & & & \\
\hline Leg. & 0.90 & 0.93 & 0.90 & 0.73 & 0.88 & 0.88 & 0.91 & 0.90 & 0.91 & & & \\
\hline Branch & & & & & & & & & & & & \\
\hline Military & 0.84 & 0.85 & 0.84 & 0.85 & 0.85 & 0.84 & 0.86 & 0.86 & 0.85 & 0.83 & & \\
\hline Const. & & & & & & & & & & & & \\
\hline Transportation & 0.93 & 0.94 & 0.90 & 0.75 & 0.91 & 0.89 & 0.94 & 0.92 & 0.93 & 0.92 & 0.83 & \\
\hline Treasury & 0.92 & 0.96 & 0.94 & 0.79 & 0.89 & 0.94 & 0.94 & 0.95 & 0.96 & 0.92 & 0.85 & 0.92 \\
\hline
\end{tabular}

Note: The numbers in each cell represent a spearman correlation (rho) between the rank ordering of members for each possible pairwise comparison. In this case, higher numbers represent a greater correlation and hence, increased consistency of voting between the two issue areas. 


\section{Table 7 Two Dimension Percent Correctly Classified Comparison}

\begin{tabular}{lcc}
\hline & W-Nominate & DW-Nominate \\
\hline Subcommittee & & \\
Ag. & 86.4 & 67.9 \\
Comm. & 86.7 & 71.5 \\
D.C. & 89.9 & 77.0 \\
Defense & 88.3 & 55.8 \\
Energy & 84.2 & 64.4 \\
Foreign Affairs & 87.3 & 67.0 \\
HUD & 87.0 & 72.8 \\
Interior & 86.6 & 73.6 \\
Labor & 90.6 & 77.8 \\
Leg. Branch & 91.8 & 74.1 \\
Military Const. & 90.6 & 61.4 \\
Transportation & 88.0 & 66.0 \\
Treasury & 85.8 & 70.4 \\
All Appropriations Votes & 85.8 & 70.3 \\
Example (104 ${ }^{\text {th }}$ Congress) & 89.1 & 70.7 \\
\hline
\end{tabular}

Note: The values in the W-NOMINATE column are based on our separate scalings while the values in the DW-NOMINATE column are based on the same votes from the "Roll-Call Estimates" file on www.voteview.com.

then be far from those positions on other bills. The movement in medians is important since many of our theories are concerned with measuring these positions correctly.

After grouping members into deciles based on voting on the 13 subcommittee bills and then comparing the deciles across bills, we found that these changes in voting patterns are not just present at the medians. Although there is a strong correlation between voting behavior on the different bills, there were still a significant number of members who may be voting in a more or less conservative fashion depending on the issue at hand. In addition, a visual inspection of Skree plots indicates that appropriations votes do not have the sharp "elbow" that we see in a plot that can more straightforwardly be described as a one-dimensional set of votes.

Based on these results, we argue that when we examine a finer grain of issues and more importantly include a sufficient number of votes, appropriations voting can be described as multidimensional. Due to the structure of agenda control, these issue areas rarely reveal themselves in conventional measures of voting behavior because these are the types of votes that party leaders want to keep from coming to the floor. For example, in the era leading up to the collapse of the Whig Party, a gag order effectively kept any debate on slavery off of the table. This does not mean that the parties were not divided on the issue, only that votes dealing with slavery did not make it to the floor. Once the Congress was forced to vote on allowing free and slave states to enter the union, for instance, then the second dimension became more dominate. The same story could be told about the Vietnam era. The parties were not necessarily internally consistent on issues dealing with the war. However, because the House took most of the votes on Vietnam in the Committee of the Whole, and not on the floor as recorded votes, we cannot use scaling procedures to call the war a second dimension issue. Based on our results, it is important to keep in mind that just because the votes are not recorded, does not mean preferences are not multidimensional.

We need to be clear, however, and state that our results do not contradict the original findings of Poole and Rosenthal. It is still the case that when grouped together, the votes taken over the course of a congress can be described by one and maybe two dimensions. Further, because we base our results on measures derived from the NOMINATE technique we are also not questioning the value of the procedure. With that in mind, we conclude by offering some advice for future research. If the question at hand deals with general patterns of decision making, then using voting scores that incorporate all votes is probably a safe bet. But, when the research design calls for predicting behavior or is examining medians and pivots on specific bills, then our results suggest that the overall measures are probably not correct and a more fine-grained measure should be used. We will leave it up to future research to develop those measures and techniques.

\section{Acknowledgments}

The authors would like to acknowledge Jeremy Duff, Suzanne Gold, and Carl Snook for their capable research assistance, seminar participants at the Political Research Workshop at the University of South Carolina and the Triangle Political Methods Group, joint Duke University and University of North Carolina, Chapel Hill, and Ryan Bakker, Jamie Carson, Josh Clinton, Keith Dougherty, Steve Smith, Tony Madonna, and especially Keith Poole for valuable advice and comments.

Manuscript submitted 19 May 2009

Manuscript accepted for publication 8 June 2010 


\section{References}

Auerswald, David, and Forrest Maltzman. 2003. "Policymaking through Advice and Consent: Treaty Consideration by the United States Senate." The Journal of Politics 65 (4): 10971110.

Binder, Sarah A. 1999. "The Dynamics of Legislative Gridlock, 1947-96." The American Political Science Review 93 (3): 519-33.

Binder, Sarah A., and Forrest Maltzman. 2002. "Senatorial Delay in Confirming Federal Judges, 1947-1998." American Journal of Political Science 46 (1): 190-99.

Black, Duncan (1948). "On the Rationale of Group DecisionMaking." Journal of Political Economy 56: 23-34.

Brady, David, and Craig Volden. 1998. Revolving Gridlock. Boulder, CO: Westview Press.

Cox, Gary W., and Mathew D. McCubbins. 1993. Legislative Leviathan: Party Government in the House. Berkeley: University of California Press.

Cox, Gary W., and Mathew D. McCubbins, 2005. Setting the Agenda: Responsible Party Government in the U.S. House of Representatives. New York: Cambridge University Press.

Cox, Gary W., and Mathew D. McCubbins. 2007. Legislative Leviathan: Party Government in the House. 2nd ed. New York: Cambridge University Press.

Clinton, Joshua, Simon Jackman, and Doug Rivers 2004. "The Statistical Analysis of Roll Call Data." American Political Science Review 98 (2): 355-70.

Crichlow, Scott. 2002. "Legislators' Personality Traits and Congressional Support for Free Trade." The Journal of Conflict Resolution 46 (5): 693-711.

Downs, Anthony. 1957. An Economic Theory of Democracy. New York: Harper.

Edwards, George C., III, Andrew Barrett, and Jeffrey Peake. 1997. "The Legislative Impact of Divided Government." American Journal of Political Science 41 (April): 545-63.

Fenno, Richard F. 1977. "U.S. House Members in Their Constituencies: An Exploration." The American Political Science Review 71 (3): 883-917.

Finocchiaro, Charles, and Jeffery Jenkins. 2008. "In Search of Killer Amendments in the Modern U.S. House." Legislative Studies Quarterly 33: 263-94.

Fiorina, Morris. 1996. Divided Government. 2nd ed. Boston: Allyn Bacon.

Gilligan, Thomas W., and Keith Krehbiel. 1990. "Organization of Informative Committees by a Rational Legislature" American Journal of Political Science 34 (2): 531-64.

Groseclose, Tim. 1994. "Testing Committee Composition Hypotheses for the U.S. Congress." The Journal of Politics 56 (2): 440-58.

Hall, Richard L., and Bernard Grofman. 1990. "The Committee Assignment Process and the Conditional Nature of Committee Bias." The American Political Science Review 84 (4): 1149-66.

Heckman, James J., and James M. Snyder, Jr. 1997. "Linear Probability Models of the Demand for Attributes with an Empirical Application to Estimating the Preferences of Legislators." The RAND Journal of Economics 28: S142S189.

Hotelling, Harold. 1929. "Stability in Competition." Economic Journal 39 (153): 41-57.
Hurwitz, Mark S., Roger J. Moiles, and David W. Rohde. 2001 "Distributive and Partisan Issues in Agriculture Policy in the 104th House" American Political Science Review 95 (December): 911-22.

Jenkins, Jeffery A., and Brian R. Sala. 1998. "The Spatial Theory of Voting and the Presidential Election of 1824." American Journal of Political Science 42 (4): 1157-79.

Jenkins, Jeffery A., and Michael C. Munger. 2003. "Investigating the Incidence of Killer Amendments in Congress." Journal of Politics 65: 498-517.

Kelly, Sean Q. 1993. "Divided We Govern? A Reassessment." Polity 25: 475-84.

Koford, Kenneth. 1989. "Dimensions in Congressional Voting." The American Political Science Review 83 (3): 949-62.

Krehbiel, Keith. 1991. Information and Legislative Organization. Ann Arbor: University of Michigan Press.

Krehbiel, Keith. 1994. "Deference, Extremism, and Interest Group Ratings.” Legislative Studies Quarterly 19 (1): 61-77.

Krehbiel, Keith. 1998. Pivotal Politics: A Theory of U.S. Lawmaking. Chicago: University of Chicago Press.

Lewis, Jeffrey B., and Keith T. Poole. 2004. "Measuring Bias and Uncertainty in Ideal Point Estimates via the Parametric Bootstrap." Political Analysis 12: 105-27.

Mayhew, David R. 1991. Divided We Govern. New Haven: Yale University Press.

Poole, Keith T., Howard Rosenthal, and Kenneth Koford. 1991. "On Dimensionalizing Roll Call Votes in the U.S. Congress." The American Political Science Review 85 (3): 955-76.

Poole, Keith T. and Rosenthal, Howard. 1991. "Patterns of Congressional Voting." American Journal of Political Science 35: 228-78.

Poole, Keith T., and Howard Rosenthal. 1997. Congress: A Political-Economic History of Roll Call Voting. New York: Oxford University Press.

Poole, Keith T., and Howard Rosenthal. 2007. Ideology and Congress. New Brunswick, NJ: Transaction Publishers.

Potoski, Matthew, and Jeffery Talbert. 2000. "The Dimensional Structure of Policy Outputs: Distributive Policy and Roll Call Voting." Political Research Quarterly 53 (4): 695-710.

Riker, William H. 1982. Liberalism against Populism. San Francisco: Freeman.

Roberts, Jason M., Steven S. Smith, and Stephen R. Haptonstahl. 2009. "The Dimensionality of Congressional Voting Reconsidered." Presented at the Duke University Conference on Bicameralism.

Rohde, David. 2010. "Political Institutions and Public Choice House Roll-Call Database.” Duke University. Unpublished manuscript.

Rosenthal, Howard. 1992. "The Unidimensional Congress Is Not the Result of Selective Gatekeeping." American Journal of Political Science 36 (1): 31-35.

Shepsle, Kenneth A., and Barry R. Weingast, 1995. "Positive Theories of Congressional Institutions." In Positive Theories of Congressional Institutions, eds. Kenneth A. Shepsle and Barry R. Weingast. Ann Arbor: University of Michigan Press.

Shipan, Charles R., and Megan L. Shannon. 2003. "Delaying Justice (s): A Duration Analysis of Supreme Court Confirmations." American Journal of Political Science 47 (4): 654-68.

Swers, Michele L. 1998. "Are Women More Likely to Vote for Women's Issue than their Male Colleagues?" Legislative Studies Quarterly 23 (3): 435-48. 
Talbert, Jeffery C., and Matthew Potoski. 2002. "Setting the Legislative Agenda: The Dimensional Structure of Bill Cosponsoring and Floor Voting." The Journal of Politics 64 (3): 864-91.

Taylor, Andrew J. 2003. "Conditional Party Government and Campaign Contributions: Insights from the Tobacco and Alcoholic Beverage Industries." American Journal of Political Science 47 (2): 293-304.

Wilkerson, John D. 1999. "'Killer' Amendments in Congress." American Political Science Review 93: 535-52.

Weingast, Barry R., and William J. Marshall. 1988. "The Industrial Organization of Congress; or, Why Legislatures,
Like Firms, Are Not Organized as Markets." The Journal of Political Economy 96 (1): 132-63.

Michael H. Crespin is Assistant Professor of Political Science, School of Public and International Affairs, The University of Georgia, 407 Baldwin Hall, Athens, GA 30602.

David W. Rohde is Ernestine Friedl Professor of Political Science, Duke University, 408B Old Chemistry, Durham, NC 27708. 